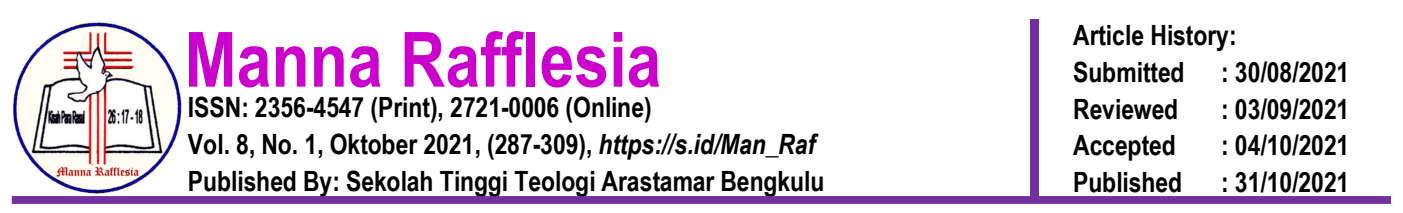

\title{
MENELISIK PERAN MISIOLOGI KAUM IBU GEREJA KAIMANTAN EVANGELIS KANAAN DALAM RANGKA HARI PEREMPUAN
}

\author{
Setinawati ${ }^{1}$ ) \\ Institut Agama Kristen Negeri Palangka Raya ${ }^{1}$ \\ *)Email Correspondence: setinawatistn@gmail.com
}

Abstract: $\quad$ This research presents the missiological role of the mothers of the GKE Kanaan Palangka Raya congregation. The role of mothers in church ministry during the Covid-19 pandemic is needed, because of the involvement and loyalty of mothers in serving. To discuss the subject of this study, researchers used qualitative methods. This method is strengthened by literature review and documentation data in the field. The results reveal the practical role of the maternal missionary in mission service at GKE Kanaan. The role is that mothers become a fundraiser section in order to support the mission service at the PI Post built by the GKE Kanaan congregation. Then the mothers of the Canaanite church testified to the community by doing social services to distribute sembako to the lesser people. Especially during the Covid-19 pandemic as it is today. To encourage and enhance the role of the mothers of the GKE Kanaan congregation in the ministry of mission, supported by the coaching factor of the church and the commitment of loyalty possessed by the mothers themselves. Loyalty includes the value of witnessing, fellowship, and serving God.

Keywords: Missiology, mothers, GKE Kanaan

Abstrak: $\quad$ Penelitian ini menyajikan peran misiologi kaum ibu jemaat GKE Kanaan Palangka Raya. Peran kaum ibu dalam pelayanan di gereja di masa pandemi covid-19 sangat dibutuhkan, oleh karena keterlibatan dan kesetiaan kaum ibu dalam melayani. Untuk membahas pokok penelitian ini, peneliti menggunakan metode kualitatif. Metode ini diperkuat dengan kajian literatur dan data dokumentasi di lapangan. Hasil penelitian mengungkapkan peran praktis misiologi kaum ibu dalam pelayanan misi di GKE Kanaan. Peran tersebut yaitu kaum ibu menjadi seksi pengumpulan dana dalam rangka mendukung pelayanan misi di Pos PI binaan jemaat GKE Kanaan. Kemudian kaum ibu jemaat Kanaan memberikan kesaksian kepada masyarakat dengan melakukan pelayanan sosial membagi-bagikan sembako pada masyarakat yang kekurangan. Terutama di masa pandemi covid-19 seperti sekarang ini. Untuk mendorong dan meningkatkan peran kaum ibu jemaat GKE Kanaan dalam pelayanan misi, didukung oleh faktor pembinaan dari gereja dan komitmen kesetiaan yang dimiliki oleh kaum ibu itu sendiri. Kesetiaan itu mencakup nilai bersaksi, bersekutu, dan melayani Tuhan.

Kata Kunci: misiologi, kaum ibu, GKE kanaan

\section{PENDAHULUAN}

Aktivitas dan kegiatan di gereja tidak lepas dari peran kaum perempuan atau ibu. Seperti yang diungkapkan oleh Jemali bahwa gereja pada hakekatnya 
tidak boleh melupakan sejarah jikalau kaum perempuan telah mengambil bagian dalam pengembangan pelayanan dan kehidupan jemaat. ${ }^{1}$ Peran perempuan atau kaum ibu dalam gereja tersebut termasuk di dalamnya keterlibatan dan dukungan dalam pelayanan misi atau pekabaran Injil. Hal ini tidak lepas dari hakikat gereja sebagai tubuh kristus yang memberitakan kabar baik. Rohi menegaskan bahwa gereja yang adalah tubuh Kristus tidak hanya diselamatkan, akan tetapi dipanggil sebagai pembawa berita dan kabar baik akan keselamatan bagi mereka yang belum percaya dan menerima Kristus sebagai Tuhan maupun Juruselamat pribadinya. ${ }^{2}$ Perempuan atau kaum ibu sebagai bagian dari gereja atau tubuh Kristus memiliki tanggung jawab yang sama sebagai pembawa berita Injil ke dalam dunia. Pelayanan misi atau pemberitaan injil dalam gereja dapat berbentuk doa, daya, dan dana. ${ }^{3}$ Bentuk pelayanan misi ini dapat dilakukan oleh kaum ibu di gereja.

Peran perempuan sebagai pembawa misi atau kabar baik ini pun menjadi bagian panggilan kaum ibu di jemaat GKE Kanaan Palangka Raya. Dimana terkait misi, gereja jemaat GKE Kanaan melaksanakan program Pemberitaan Kabar Baik (PKB) berdasarkan visi dan misi GKE Kanaan, yaitu yang berkaitan dengan program perwujudan kesaksian melalui kegiatan bersama jemaat. PKB sebagai badan Misi GKE yang fokusnya pada penginjilan ke luar dan pembinaan ke dalam bagi warga GKE menjadi tanggung jawab kaum ibu untuk merealisasikannya. Peran dan tanggung jawab kaum ibu ini tentu tidak mudah.

\footnotetext{
1 Maksimilianus Jemali, "Upaya Pastoral Untuk Meningkatkan Peran Kaum Perempuan Dalam Kehidupan Menggereja," Jurnal Pendidikan Dan Kebudayaan 10, no. 2 (2018): 204-18, http://unikastpaulus.ac.id/jurnal/index.php/jpkm/article/view/171.

2 Yohanis Udju Rohi, "Hakekat Misi Yesus Kepada Para Murid Dalam Matius 10 : 1-15 Sebagai Dasar Misi Gereja," Missio Ecclesiae 3, no. 2 (2014): 162-82, https://doi.org/https://doi.org/10.52157/me.v3i2.42.

3 Malik, "Implementasi Menjadi Jemaat Yang Misioner," Phronesis: Jurnal Teologi Dan Misi 2, no. 2 (2019): 124-139.
} 
Gereja sebagai lembaga perlu membekali kaum ibu. Terlebih, untuk membantu perempuan atau kaum ibu bertumbuh dari aspek rohani, gereja harus membantu kaum ibu dalam menggunakan karunia rohani yang dimiliki, serta mendorong kaum ibu untuk aktif serta berpartisipasi dalam kegiatan dan karya pelayanan yang ada di gereja. ${ }^{4}$ Senada dengan itu, Elim menegaskan, adalah lebih baik kaum perempuan menggunakan talenta yang dimiliki oleh anugerah Allah untuk melayani dan memuliakan Tuhan. ${ }^{5}$ Upaya ini penting dilakukan agar kaum ibu memiliki kemampuan dan hati untuk membantu dan melaksanakan pelayanan misi pemberitaan Injil dengan baik.

Merujuk kepada peran kaum ibu jemaat GKE Kanaan dalam misi tersebut, sejalan dengan arahan Ketua Umum Majelis Sinode GKE Pdt. Dr. Simpon F. Lion, M.Th dalam rangka memperingati "Hari Perempuan GKE Tahun 2021." Dimana Ketua Mejelis Sinode memberikan refleksi dengan tema "Perempuan GKE Selalu sehati sepikir dalam bersaksi, bersekutu, dan melayani demi kemuliaan nama Tuhan (Wahyu 22:12-13)." Tema refleksi ini menjadi dasar dan motivasi bagi kaum ibu Jemaat GKE Kanaan dalam menghidupi dan mendukung pelayanan misi di gereja.

Berdasarkan ulasan di atas, penulis mencoba memberikan kajian terkait peran misiologi kaum ibu di jemaat GKE Kanaan Palangka Raya. Kajian ini didasari dengan sebuah rumusan masalah, yaitu sejauh mana peran misiologi kaum ibu jemaat GKE Kanaan Palangka Raya, terutama pelayanan misi di masa

\footnotetext{
4 Nunuk Rinukti Siahaya, "Peranan Perempuan Menurut Perjanjian Baru Bagi Perkembangan Kepemimpinan Perempuan Di Dalam Gereja," Jurnal Teruna Bhakti 1, no. 1 (2018): 33-41, http://ejournal.stakterunabhakti.ac.id/index.php/teruna/article/view/9.

5 Elim Simamora, "Peranan Perempuan Dalam Gereja : Eksposisi 1 Korintus 14 : 34," Kerugma: Jurnal Teologi Dan Pendidikan Kristen 1, no. 2 (2019): 75-89.
} 
pandemi covid-19? Dengan demikian, tulisan ini bertujuan untuk menemukan dan menganalisis peran misiologi kaum ibu di jemaat GKE Kanaan Palangka Raya.

\section{METODE}

Peneliti menggunakan metode kualitatif dalam kajian penelitian ini. Pendekatan ini biasanya digunakan untuk meneliti keadaan atau kondisi obyek yang alamiah, dimana peneliti dalam posisi instrumen kunci, kemudian teknik dalam mengumpulkan data menggunakan triangulasi atau gabungan, lalu analisis data yang digunakan bersifat kualitatif, serta pembahasan hasil penelitian kualitatif menekankan pada makna ketimbang sebagai generalisasi. ${ }^{6}$ Peneliti akan mendeskripkan hasil penelitian terkait misi dan peran kaum ibu dalam jemaat GKE Kanaan. Studi literatur dan dokumentasi peneliti lakukan untuk mendapatkan data dan analisis terhadap topik yang dibahas. Dalam tulisan ini, pada awal pembahasan peneliti memaparkan hasil literature terkait hakikat misi dan peran pelayanan kaum ibu dalam gereja. Kemudian peneliti akan menganalisis data dokumentasi di lapangan serta memadukannya dengan kajian literatur. Hasil analisis tersebut kemudian peneliti menarik kesimpulan atas temuan dan kajian atas data penelitian terkait peran misiologi kaum ibu di jemaat GKE Kanaan Palangka Raya.

\section{HASIL}

Penelitian ini memberikan hasil tentang beberapa unsur misi yang dapat memperkuat pemahaman pelayanan misi oleh kaum ibu di GKE Kanaan,

${ }^{6}$ Sugiyono, Metode Penelitian Pendidikan (Bandung: Alfa Beta, 2016). 
Palangka Raya. Berikut hasil penelitian yang ditemukan, yaitu tentang konsep inti misi yang diuraikan dalam tiga bagian, pertama, proklamasi keselamatan. Kedua, kesaksian dan ketiga, pelayanan. Selanjutnya unsur utama dalam proses Pekabaran Injil, yaitu: pertama, manusia sebagai pelaku dan pemberita Injil. Kedua, unsur isi berita yang dibawa pemberita Injil. Ketiga, unsur metode atau pola pendekatan yang digunakan pemberita Injil. Kemudian metode pelayanan misi, yaitu: pertama, metode penginjilan di hadapan orang banyak. Kedua, penginjilan pribadi. Untuk penginjilan pribadi pada era normal baru ada tiga hal yang perlu diperhatikan, yaitu fokus penginjilan pribadi, peranan dan karya Roh Kudus dan melatih diri. Ketiga, metode penginjilan kelompok. Penelitian ini juga mengahsilkan terobosan baru bagi kaum ibu di jemaat GKE Kanaan Palangka Raya secara khusus untuk jenis Pelayanan yang perlu dikembangkan, yaitu: pelayanan Sekolah Minggu, Pelayanan Persekutuan Wanita, Pelayanan Penginjilan, Pelayanan Kunjungan dan Pendalaman Alkitab. Hasil penelitian ini juga menemukan peran misiologi kaum Ibu jemaat GKE Kanaan Palangka Raya dan upaya peningkatan peran misiologi kaum Ibu jemaat GKE Kanaan Palangka Rayam baik dalam bidang etis dan bidang kehidupan sosial. Seluruh hasil penelitian tersebut akan dijelaskan pada bagian pembahasan.

\section{PEMBAHASAN}

Pada bagian ini penulis akan membahas beberapa unsur misi yang dapat memperkuat pemahaman dan implementasi pelayanan misi oleh kaum ibu di gereja. Unsur tersebut di antaranya: inti misi, unsur utama dalam proses 
pekabaran injil, metode pelayanan misi, serta beberapa jenis pelayaan kaum ibu di gereja. Unsur-unsur tersebut akan dijabarkan dalam uraian berikut ini.

\section{Inti Misi}

Misi identik dengan istilah penginjilan. Sondopen menjelaskan bahwa misi tidak dapat dipisahkan dengan penginjilan, penginjilan pun tidak dapat dipisahkan dengan misi. Dimana penginjilan merupakan bentuk proklamasi Injil Yesus Kristus bersifat berkuasa dan mengena, serta dapat dipahami, yang membawa pertobatan kepada Yesus Kristus. ${ }^{7}$

Berkaitan dengan makna misi yang identik dengan penginjilan, akan dibahas berikut ini. Kristian mengungkapkan makna penginjilan sebagai berikut: ${ }^{8}$ pertama, penginjilan merupakan suatu tanggung jawab mengumumkan dan memberitakan kabar baik bahwa keselamatan ada di dalam Yesus Kristus. Kedua, penginjilan diimplementasikan dengan seruan seperti seorang utusan kerajaan yang mengumumkan sebuah dekrit, dengan mengucapkan suara dengan keras dan tegas, sama halnya ketika mengajar kepada murid-murid, kemudian bersaksi sesuai dengan pengalaman pemberita Injil tersebut. Ketiga, tanggung jawab penginjilan merupakan keharusan dan tidak dapat diabaikan, karena misi dan berita penginjilan menyangkut berita keselamatan kepada banyak orang.

Berdasarkan pemahaman misi tersebut, terkandung inti dari misi. Inti misi dapat diuraikan dalam beberapa tiga bagian. Bagian tersebut adalah sebagai berikut: $^{9}$ pertama, proklamasi keselamatan. Gereja atau orang percaya dipanggil

\footnotetext{
7 Dorce Sondopen, "Relasi Antara Penginjilan Dan Pemuridan Untuk Pertumbuhan Gereja," Excelsis Deo: Jurnal Teologi, Misiologi, Dan Pendidikan 4 (2019): 95-105.

8 Alvin Budiman Kristian, "Pemberitaan Injil Di Tengah Masyarakat Pluralis," Excelsis Deo: Jurnal Teologi, Misiologi, Dan Pendidikan 3, no. 1 (2019): 123-32, https://doi.org/10.51730/ed.v3i1.5.

${ }^{9}$ Nur Budi Santosa, "Pelayanan Sosial Sebagai Konteks Refleksi Aktivitas Misiologi," Antusias: Jurnal Teologi Dan Pelayanan 2, no. 4 (2013).
} 
untuk memproklamirkan kristus kepada dunia. Berita keselamatan dan pengampunan dosa yang harus diberitakan dan disebarluaskan. Kedua, kesaksian. Kesaksian menceritakan pengalaman pribadi bagaimana Tuhan Yesus telah menyelamatkannya. Ketiga, pelayanan. Pelayanan yang dimaksud yaitu pelayanan diakonia. Dimana terkandung perwujudan kasih yang berbentuk pelayanan sosial yang misioner.

\section{Unsur Utama Dalam Proses Pekabaran Injil}

Konsep berikutnya yang perlu dipahami oleh kaum ibu dalam melaksanakan misi ialah unsur-unsur dalam proses pekabaran Injil. Berikut ini terdapat beberapa unsur dalam proses pekabaran Injil. Unsur-unsur tersebut ialah: ${ }^{10}$ pertama, manusia sebagai pelaku dan pemberita Injil. Peran pembawa berita Injil hendaknya memiliki nilai yang dapat dipercaya oleh orang yang mendengar berita atau menerima berita. Kemudian memiliki sebuah keyakinan yang kuat terhadap kebenaran dan Injil keselamatan yang diberitakan, serta memiliki motivasi kebaikan dan kasih yang tulus ketika mmemberitakan Injil atau kabar baik yang dibawanya. Dengan demikian, penerima berita kabar baik tersebut, akan dengan mudah menerima berita tersebut, dan apabila ia menerima dengan jelas, maka hatinya akan siap dan menerima berita Injil tersebut.

Kedua, unsur isi berita yang dibawa pemberita Injil. Isi berita yang baik ialah berpusat pada pesan dan berita Injil itu sendiri, yang memuat bahwa Allah sangat mengasihi manusia (Yoh. 3:16) serta Allah memiliki rencana indah dan mulia bagi kehidupan manusia (Yoh. 10:10b). 2007).

10 Tim LPMI, Latihan Pemuridan Dasar (Surabaya: Lembaga Pelayanan Mahasiswa Indonesia, 
Ketiga, unsur metode atau pola pendekatan yang digunakan pemberita Injil. Pola pemberitaan yang digunakan pemberita Injil hendaknya berpusat pada nilai dan prinsip komunikasi yang baik dan benar, bukan berpusat dalam diri sendiri. Selanjutnya, pola pembawa berita Injil juga hendaknya berpusat dan fokus pada pendengar. Pemberitaan Injil yang berpusat pada pendengar, perlu mempertimbangkan pendekatan apa yang digunakan. Selain itu, perlu juga memperhatikan keseimbangan baik antara pendekatan persahabatan maupun dengan pendekatan konfortatif.

\section{Metode Pelayanan Misi}

Konsep berikutnya terkait misi ialah memahami metode pelayanan misi. Kristian mengungkapkan beberapa metode palayanan misi. Metode tersebut di antaranya: ${ }^{11}$ pertama, metode penginjilan di hadapan orang banyak. Metode penginjilan di hadapan orang banyak ini biasanya dilakukan murid-murid Yesus di zaman Perjanjian Baru. Misalnya dilakukan di Sinagoge. Bentuk penginjilan seperti ini pada di jaman sekarang, dapat dilaksanakan dan dilakukan di tempat atau ruang ibadah, serta ibadah kebangunan rohani yang dilaksanakan di lapangan terbuka.

Kedua, penginjilan pribadi. Metode ini biasanya berdasarkan daya nalar dari pembawa berita dan disesuaikan dengan penerima Injil. Metode ini akan efektif jika penginjil membangun relasi atau persahabatan dengan orang yang diinjili. Yang terpenting dari metode ini ialah penginjil bekerja sama dengan gereja lokal dengan tujuan agar orang yang diinjili dapat diterima dan dilayani lebih lanjut oleh gereja lokal tersebut. Berkaitan dengan penginjilan pribadi,

11 Kristian, "Pemberitaan Injil Di Tengah Masyarakat Pluralis." 
Edwin Gandaputra menjelaskan ada tiga hal yang tersirat dalam memikirkan ulang kebiasaan baru dalam era new normal yaitu sebagai berikut: ${ }^{12}$ pertama, fokus penginjilan pribadi. Penginjilan pribadi didasarkan kepada kasih Kristus yang dialami secara nyata oleh seorang yang rindu menjaga semangat penginjilan pribadi. Fokus penginjilan pribadi adalah Kristus sang Mesias. Pengalaman indah akan dialami seseorang bersama Kristus, apabila hidupnya fokus pada pengenalan akan ajaran Yesus Kristus. Fokus tersebut akan membawa motivasi dan semangat untuk melakukan penginjilan pribadi. Kedua, peranan dan karya Roh Kudus. Peranan dan karya Roh Kudus akan menolong seseorang untuk melakukan Amanat Tuhan Yesus dan mengalami kasih Allah yang besar. Roh Kudus memampukan dan menolong orang Kristen untuk hidup dalam kebenaran Allah. Kemudian, Roh Kudus juga menolong dan memampukan orang percaya untuk dapat memahami firman Tuhan, berdoa, dan melayani Tuhan. Ketiga, melatih diri. Tuhan Yesus memberikan keteladanan dalam pergi memberitakan Injil. Tuhan Yesus melatih murid-murid untuk menghadapi rasa takut, meningkatkan kemampuan diri dengan berbagai kemampuan.

Ketiga, metode penginjilan kelompok. Metode ini lebih bersifat dan memiliki karakter kekeluargaan, dimana ada interaksi tentang persoalan dan masalah pribadi, maupun masalah tentang kerohanian yang diceritakan dan dibagi pada sesama anggota. Keempat, metode penginjilan perkunjungan rumah. Metode ini lebih mengutamakan kunjungan rumah dan melayani setiap orang yang berada dan tinggal dalam rumah yang dilayani.

12 Edwin Gandaputra, "Memikirkan Ulang Aplikasi Penginjilan Pribadi Pada Masa New Normal," Saint Paul's Review 1, no. 1 (2021): 29-45. 


\section{Jenis Pelayanan Kaum Ibu Di Gereja}

Pelayanan misi di gereja dapat ditemui dalam setiap bentuk pelayanan yang dapat dilakukan oleh kaum ibu. Adapun bentuk pelayanan tersebut di antaranya: ${ }^{13}$

\section{Pelayanan Sekolah Minggu}

Pelayanan Sekolah Minggu merupakan pelayanan yang diibaratkan sebuah pelayanan gereja dalam gereja. Pada prinsipnya, setiap departemen yang ada di gereja mesti diperlakukan sama, dimana berbagai bentuk pelayanan bisa dilaksanakan dalam gereja. Palayanan Sekolah Minggu dapat berupa kunjungan penggembalaan pada anak, pelayanan pemberitaan kabar baik pada anak, camp pada anak-anak, sekolah kabar baik dan Alkitab liburan untuk anak-anak, retreat anak-anak, paduan suara untuk anak-anak, pelayanan perpustakaan dan literatur sekolah minggu untuk anak-anak, serta bentuk pelayanan lainnya untuk anakanak.

\section{Pelayanan Persekutuan Wanita}

Bentuk pelayanan berikutnya yang dapat diiukuti dan dilakukan oleh kaum ibu ialah pelayanan di Persekutuan Wanita. Pelayanan tersebut kaum ibu dapat mengambil peran pelayanan sebagai berikut: pertama, peran penanggunjawab persekutuan wanita. Peran ini bertugas untuk mengembangkan pelayanan dalam persekutuan tersebut. Untuk itu sebagai penanggung jawab perlu membekali diri dan mengisi kemampuan diri dengan pengetahuan yang baik tentang tugas dan pelayanannya. Kedua, berperan dalam menyusun dan melaksanakan pelayanan rutin kaum wanita. Ketiga, berperan memberikan pelayanan khotbah dan

${ }^{13}$ Malik Bambangan et al., "Pemberdayaan Kaum Ibu Dalam Pelayanan Di Gksi Sektor Kuala Behe Kecamatan Kuala Behe Kabupaten Landak Kalimantan Barat," Jurnal PKM Setiadharma 1, no. 1 (August 18, 2020): 19-26, https://doi.org/10.47457/jps.v1i1.41. 
mengajar untuk perkembangan dan pertumbuhan kaum wanita. Keempat, berperan untuk melaksanakan pelayanan kunjungan pada anggota wanita maupun kaum wanita pendatang baru. Kelima, berperan melaksanakan perkunjungan bagi mereka yang sakit, tidak aktif, dan lain sebagainya. Keenam, berperan melaksanakan rapat atau pertemuan persekutuan wanita. Ketujuh, menggembalakan atau melayani kaum wanita dengan hati yang tulus. Serta berperan dalam pengembangan dan pelayanan-pelayanan kaum wanita lainnya untuk memuliakan Tuhan.

\section{Pelayanan Penginjilan}

Pelayanan penginjilan bukan hanya tugas pendeta atau seorang penginjil. Namun penginjilan hakekatnya dapat dilakukan oleh setiap orang percaya, termasuk kaum wanita. Terkait itu, pelayanan penginjilan yang dapat dilakukan oleh kaum wanita adalah sebagai berikut: pertama, memberikan pelatihan rutin yang mendidik jemaat dalam pelayanan penginjilan pribadi. Pelatihan ini dapat diatur beberapa kali secara berkala atau dapat juga dilakukan secara terusmenerus. Pelayanan penginjilan membutuhkan pemahaman yang baik dan kemampuan yang cukup. Sehingga penginjilan dapat dilakukan dengan baik dan tepat. Kedua, melaksanakan kegiatan seminar penginjilan bagi jemaat. Ketiga, membentuk tim pelayanan penginjilan tiap minggu. Keempat, menyusun dan melaksanakan kegiatan penginjilan lewat ibadah KKR. Tujuan dari ibadah KKR ini adalah untuk menginjili orang-orang yang belum percaya kepada Kristus. Ibadah KKR ini tidak dimaksudkan menginjili jemaat lain untuk pindah gereja. Kelima, melaksanakan kegiatan dan pelayanan penginjilan rutin bagi orang-orang tertentu di luar gereja maupun yang ada di masyarakat. 


\section{Pelayanan Kunjungan}

Pelayanan kunjungan dalam geraja merupakan bagian tidak terpisahkan dari pelayanan-pelayanan yang ada di gereja. Pelayanan kunjungan tidak sekedar berkunjung ke rumah jemaat atau sekedar bertanya kepada jemaat soal tidak hadir dalam ibadah gereja atau lainnya, namun ada berita kabar baik dan firman Allah yang disampaikan untuk memperkokoh dan mengingatkan jemaat yang dilayani dan dikunjungi. Kemudian pelayanan kunjungan bukan berarti hanya untuk jemaat yang tidak hadir dalam ibadah di gereja, jemaat yang sakit atau malas, akan tetapi berupa penggembalaan dan kepedulian gereja pada jemaat yang dilayani. Untuk itu, pelayanan di gereja jangan hanya sibuk dalam gereja, namun penting juga melaksanakan pelayanan kunjungan bagi jemaat yang tidak hadir ibadah minggu.

Selanjutnya, terdapat beberapa aspek yang dapat dilakukan oleh pelayan dalam program pelayanan perkunjungan. Pertama, pelayanan memberikan motivasi jemaat untuk ambil bagian dalam tim pelayanan kunjungan. Kedua, menyusun jadwal kegiatan kunjungan harian maupun mingguan. Ketiga, menyusun program pelatihan terkait pelayanan kunjungan. Keempat, melaksanakan kegiatan pelayanan kunjungan bagi orang sakit, orang lemah, jemaat yang tidak aktif, dan pelayanan lainnya. Kelima, pelayanan kepada jemaat yang dikunjungi dan memberikan arahan untuk bergabung dalam persekutuan yang ada di dalam gereja. Keenam, melakukan pelayanan yang membantu tim kunjungan dalam pelayanan bagi jemaat baru dalam gereja. 


\section{Pendalaman Alkitab}

Bentuk pelayanan berikutnya yang dapat dilakukan kaum ibu ialah kelas atau program Pendalaman Alkitab (PA). Program PA ini membantu jemaat untuk mendalami kebenaran Alkitab dan membantu jemaat untuk bertumbuh secara rohani. Pelayanan program PA dapat dilakukan dalam beberapa bentuk. Misalnya, pelayanan PA untuk wanita menikah, wanita tidak menikah, muda-mudi, dan lain sebagainya. Kelompok pelayanan PA biasanya dipimpin oleh peyanan yang ditetapkan oleh pimpinan dan majelis gereja. Pelayanan kelompok PA untuk lakilaki maka akan dipimpin oleh seorang laki-laki. Demikian sebaliknya, kelompok perempuan akan dipimpin oleh perempuan. Pemimpin dalam kelompok PA tentu harus memiliki kemampuan dalam memimpin kelompoknya untuk melakukan kegiatan pelayanan bersama-sama. Bagian ini penting dalam membangun tim dalam pelayanan PA, sehingga terjadi pertumbuhan rohani anggota tim maupun jemaat yang dilayani.

\section{Peran Misiologi Kaum Ibu Jemaat GKE Kanaan}

Berdasarkan data yang peneliti peroleh dari dokumentasi dan adminitrasi gereja di jemaat GKE Kanaan, peneliti memperoleh informasi terkait pelayanan misi dengan istilah program Pemberitaan Kabar Baik (PKB). Dari sumber data administrasi gereja GKE Kanaan, jumlah kaum ibu ialah 300 orang. Kemudian kaum ibu yang aktif dalam pelayanan misi dan dalam gereja ialah 80 orang.

PKB GKE merupakan sarana memberitakan Injil amanat agung bagi semua orang percaya. Fokus dari pemberitaan Injil adalah Yesus Kristus Tuhan dan Juruselamat (2Tim.1: 8, 2Kor. 4: 3, Mrk 1: 38). PKB GKE sebagai wadah sekaligus badan Misi GKE yang fokusnya pada penginjilan ke luar dan 
pembinaan ke dalam bagi warga GKE. Pemantapan PKB dilaksanakan dalam bentuk pelatihan terutama kepada pendeta dan vikaris yang melayani di berbagai pos PI untuk membina dan menjangkau jiwa-jiwa. Demikian juga untuk memperlengkapi jemaat. Pelatihan dan pembinaan ini sejalan dengan pendapat Malik dkk, dijelaskan bahwa memberikan pelatihan rutin yang mendidik jemaat dalam pelayanan penginjilan akan menolong jemaat atau kaum ibu terkait pemahaman yang baik dan kemampuan yang cukup, sehingga penginjilan dapat dilakukan dengan baik dan tepat. ${ }^{14}$

Gereja Kanaan melaksanakan program Pemberitaan Kabar Baik (PKB) berdasarkan visi dan misi GKE Kanaan yang berkaitan dengan program perwujudan kesaksian melalui kegiatan bersama jemaat. PKB sebagai wadah sekaligus badan Misi GKE yang fokusnya pada penginjilan ke luar dan pembinaan ke dalam bagi warga GKE. Tujuan PKB GKE memberitakan Injil selain di mimbar gereja, ibadah rumah tangga, dan kebaktian kategorial, memberitakan injil dapat disampaikan kepada siapa saja.

Secara praktis PKB jemaat GKE Kanaan dilaksanakan dalam bentuk pelatihan dan mempersiapkan dana dari donator dan mitra-mitra yang mendukung pendeta dan vikaris untuk melayani, membina, dan menjangkau jiwa-jiwa di berbagai tempat POS PI. Pos PI yang sementara dibantu saat ini seperti lokasi POS PI PKB di Hulu Jojabo Resort GKE Delang dan di wilayah Tepian Kahui Resort Timpah. Untuk membiayai dua pos PI ini, jemaat Kanaan memberikan dukungan dana untuk membiayai pelayan Pos PI sebesar Enam Juta untuk dua orang. Yang mengumpulkan dana terdiri dari seksi pelayan ibu-ibu dan

14 Malik et al. 
perkumpulan bapak-bapak. Untuk seksi pelayanan ibu-ibu mendukung Pos PI PKB Desa Tepian Kahui, dan perkumpulan bapak-bapak mengumpulkan dana untuk pelayanan di Pos PI PKB desa Jejabo. Dukungan pengembagan Pos PI sejalan dengan pendapat Simon dan Angkouw, yang menegaskan bahwa untuk mendukung terciptanya gerakan perintisan gereja perlu kontribusi organisasi gereja. ${ }^{15}$ Hal ini pun dilakukan oleh gereja jemaat GKE Kanaan.

Terkait upaya pengumpulan dana yang dilakukan oleh kaum ibu jemaat GKE Kanaan, merupakan tindakan praktis dalam memajukan pelayanan misi. Di masa pandemi covid-19 pelayanan seperti ini sangat dibutuhkan oleh masyarakat. Pandemi covid-19 pada umumnya telah berdampak pada kondisi ekonomi masyarakat, sehingga pemenuhan kebutuhan sehari-hari masyarakat pun terganggu. Sekalipun kondisi ekonomi tidak stabil karena pandemi, komitmen kaum ibu untuk terus mendukung pelayanan misi di Pos PI binaan GKE Kanaan Palangka Raya tetap dan terus jalan. Pelayanan misi ini menjadi program rutin di jemaat GKE Kanaan. Komitmen ini menunjukkan bahwa kaum ibu jemaat Kanaan sangat serius dan memiliki hati yang dalam untuk mendukung pelayanan misi. Peran kaum ibu ini sejalan dengan kajian Agus Surya, yang menekankan bahwa peran dan kewajiban perempuan dalam pelayanan jemaat di gereja tidak dibatasi oleh kondisi dan status, perempuan memiliki kewajiban yang sama dengan laki-laki dalam pelayanan, serta memiliki nilai yang sama bagi Tuhan

15 Simon and Semuel Ruddy Angkouw, "Perintisan Gereja Sebagai Bagian Dari Implementasi Amanat Agung," Manna Rafflesia 7, no. 2 (April 30, 2021): 210-34, https://doi.org/10.38091/man_raf.v7i2.142. 
Yesus. ${ }^{16}$ Dalam mendukung pelayanan dan pengembangan pelayanan Pos PI binaan GKE Kanaan, kaum ibu memiliki peranan yang sama dengan bapak-bapak. Pelayanan misi yang dilakukan oleh kaum ibu, selain mendukung dan menjadi seksi mengumpulkan dana, kaum ibu jemaat kanaan juga melakukan aksi misi sederhana dengan membagi-bagikan sembako kepada mereka yang kekurangan dan terdampak covid-19. Pelayanan sosial atau holistik ini merupakan bagian dari kontekstualisasi Injil Yesus Kristus dalam kehidupan sehari-hari yang terjadi di lingkungan sekitar gereja. Pelayanan ini juga sebagai upaya dalam merealisasikan dan mewujudkan pengajaran Alkitab ke dalam praksis kehidupan, yang terjadi di tengah-tengah situasi dan kondisi konkret yang ada di sekitar gereja. Pelayanan Yesus sendiri tidak hanya fokus pada Pemberitaan Injil. Akan tetapi juga pelayanan penobatan yang membuat seseorang menjadi murid Kristus, kemudian murid tersebut menjadi percaya dan memperoleh keselamatan jiwa, serta pelayanan yang bersifat holistik, dimana Yesus sendiri memperhatikan kebutuhan sosial murid tersebut. ${ }^{17}$ Tindakan praktis kaum ibu dalam pelayanan sosial ini sejalan dengan tema Hari Perempuan GKE Kanan, yaitu "Perempuan GKE selalu sehati sepikir dalam bersaksi, bersekutu, dan melayani demi kemuliaan nama Tuhan." Nilai dati tema Hari Perempuan GKE ini menjadi penyemangat motivasi kaum ibu untuk terus bersaksi, bersekutu, dan melayani.

Tindakan praktis lainnya yang dapat dilakukan oleh kaum ibu dalam pelayanan misi ialah dengan berbagi kesaksian atau tulisan-tulisan firman Tuhan

${ }^{16}$ Agus Surya, "Peran Perempuan Dalam Ibadah: Dialektika Politik Dan Teologi Tubuh," SOTIRIA (Jurnal Theologia Dan Pendidikan Agama Kristen) 3, no. 2 (2020): 84-94, https://doi.org/10.47166/sot.v3i2.22.

17 Kalis Stevanus, "Mengimplementasikan Pelayanan Yesus Dalam Konteks Misi Masa Kini Menurut Injil Sinoptik," FIDEl: Jurnal Teologi Sistematika Dan Praktika 1, no. 2 (2018): 284-98, https://doi.org/10.34081/fidei.v1i2.21. 
yang menguatkan melalui media sosial. Hal sederhana ini dapat dilakukan oleh kaum ibu melalui media sosial yang dimiliki oleh kaum ibu, seperti facebook dan WhatsApp. Apalagi diindikasikan kaum ibu memiliki perkumpulan melalui WhatsApp group. Pada masa pandemi covid-19, kaum ibu sangat dekat dan familiar menggunakan media sosial tersebut dan dapat berbagi informasi. Penerima pesan tidak terbatas dan mencakup semua orang yang melihat dan mendengar pesan dan kesaktian yang dipublikasikan. Terkait penggunaan aplikasi dan media sosial ini, Waruwu dan Purdaryanto mengungkapkan bahwa berita Injil dapat dibuat dan disuguhkan dalam bentuk tulisan, audio, serta video yang kemudian dibagikan melalui media sosial. Bentuk pelayanan media sosial ini, dapat memberikan kesempatan dan peluang yang besar dalam mengerjakan dan melaksanakan Amanat Agung Tuhan Yesus pada masa pandemi covid-19. ${ }^{18}$

Pelayanan dan kegiatan misi kaum ibu jemaat GKE Kanaan ini memiliki peranan yang sangat strategis untuk melayani jiwa-jiwa, terutama dukungan dalam dana misi. Terutama posisi dan keberadaan jemaat GKE Kanaan berada di daerah kota. Dimana wilayah perkotaan penuh dengan problematika kehidupan. Jonar Situmorang menerangkan bahwa pelayanan dan program misi perkotaan perlu mendapat perhatian serius dari gereja. Hal ini karena di wilayah perkotaan terdapat berbagai macam permasalahan kehidupan. Permasalahan yang umumnya banyak terjadi di perkotaan ialah adanya kesenjangan sosial di masyarakat, yang membuat orang lain enggan dan tidak mau dekat dengan gereja. Kemudian ditambah faktor keegosian masyarakatnya dan sikap mementingkan kepentingan

${ }^{18}$ Adieli Waruwu and Samuel Purdaryanto, "Strategi Pelayanan Misi Dimasa Pandemi Coronavirus Desease 2019," Manna Rafflesia 7, no. 2 (2021): 419-40, https://doi.org/10.38091/man_raf.v7i2.171. 
sendiri yang membuat tidak peduli kepada sesama. ${ }^{19}$ Kondisi ini menjadi tantantan tersendiri bagi kaum ibu jemaat GKE Kanaan dalam mengemban pelayanan misi.

\section{Upaya Peningkatan Peran Misiologi Kaum Ibu Jemaat GKE Kanaan}

Kaum ibu dalam meningkatkan peran misiologinya, tidak lepas dari peran gereja dan kesetiaan kaum ibu jemaat GKE Kanaan dalam bersaksi, bersekutu, dan melayani. Peran gereja dalam pemberdayaan kaum ibu dapat dilakukan dengan pelatihan, pemetaan peran sosial, dan pengembangan talenta kaum ibu. ${ }^{20}$ Untuk pemetaan peran sosial, melihat peran kaum ibu dalam keluarga yaitu apakah sebagai sebagai seorang gadis, wanita muda, isteri dari seorang suami, ibu bagi anak-anaknya, nyonya rumah dengan pramuwismanya, serta nenek bagi janda. Shintia dkk menegaskan bahwa tugas utama perempuan dalam kehidupan keluarga, perempuan juga dalam perkembangannya terlibat dalam pelayanan ibadah dan kepemimpinan. Pada masa kini, perempuan pun memiliki dan mempunyai kesempatan yang sama untuk terlibat di dalam pelayanan tersebut, termasuk pelayanan misi. ${ }^{21}$ Artinya, peran kaum ibu dalam pelayanan misi sangat dibutuhkan dalam gereja.

Terkait pelatihan, erat kaitannya dengan memperlengkapi jemaat atau kaum ibu untuk bersaksi. Tacoy menegaskan bahwa pemimpin gereja perlu melatih setiap anggota jemaat dalam pelayanan misi amanat Agung Tuhan Yesus. Pelatihan misi ini sangat penting, agar jemaat memiliki pemahaman dan

19 Jonar Situmorang, "Model Misi Perkotaan Rasul Paulus Di Korintus," Missio Ecclesiae 7, no. 2 (2018): 188-228.

20 Siahaya, "Peranan Perempuan Menurut Perjanjian Baru Bagi Perkembangan Kepemimpinan Perempuan Di Dalam Gereja."

${ }^{21}$ Shintia Maria Kapojos, Randy Frank Rouw, and Hengki Wijaya, "Implikasi Kehidupan Perempuan Yahudi Bagi Gereja Masa Kini," Evangelikal: Jurnal Teologi Injili Dan Pembinaan Warga Jemaat 3 (2019): 136-43. 
kemampuan dalam pelayanan misi serta siap menjadi saksi Kristus di lingkungan dimana dirinya berada. Selain itu, dengan pelatihan misi, jemaat memperoleh rasa percaya diri dalam melaksanakan amanat agung sekaligus untuk meminimalisir berbagai kesalahan yang mungkin dapat terjadi dalam melaksanakan pelayanan misi tersebut. ${ }^{22}$ Kemudian, selain pelatihan memperlengkapi kaum ibu bersaksi, gereja juga dapat memakai jalur pengembangan talenta atau karunia-karunia rohani yang dimiliki oleh jemaat. Hal ini penting, agar kaum wanita dapat menjalankan perannya dengan pelayanan dan talenta yang sesuai.

Upaya berikutnya dalam meningkatkan peran kaum ibu jemaat GKE dalam pelayan misi di gereja ialah dengan membangun nilai kesetiaan. Chang menegaskan bahwa kesetiaan akan membuahkan kesaksian dalam bidang etis dan sosial. ${ }^{23}$ Penjelasan lebih lanjut terkait bidang tersebut yaitu: pertama, bidang etis. Bidang etis artinya bahwa kehidupan iman yang memberikan kesaksian, dimana kehidupan moral yang kristiani dihidupi kembali. Kehidupan iman tersebut sesuai dengan firman dan rahmat Allah, yang membawa seorang Kristen menjadi saksi dan pribadi yang setia. Kesetiaan kepada Allah pada waktu yang sama menunjukkan kesetiaan kepada diri sendiri. Kesaksian dan kesetiaan seorang percaya yang menerima Kristus akan dengan sendirinya mewujudkan kebenaran dan memberikan kesaksian hidup sebagai ciptaan baru di dalam Kristus (2Kor 5: 17).

Kedua, bidang kehidupan sosial. Artinya, kesaksian dan kesetiaan kehidupan iman orang percaya akan membawa pengaruh pada lingkungan sekitar, termasuk dalam kehidupan sosial politik dalam masyarakat maupun secara luas

22 Selvester Melanton Tacoy, "Pelayanan Dalam Konteks Masyarakat Perkotaan," Jurnal Teologi Kontekstual Indonesia 1, no. 1 (2020): 36, https://doi.org/10.46445/jtki.v1i1.300.

23 William Chang, Menggali Butir-Butir Keutamaan (Yogyakarta: Kanisius, 2002). 
dalam Negara. Dalam kehidupan sosial ini, iman kristiani tidak bisa tinggal sebagai teori ilmu pengetahuan belaka, namun harus diwujudkan dalam cara pikir dan tindak tanduk yang nyata. Penjelasan Chang ini menegaskan bahwa membangun kesetiaan dalam diri kaum ibu jemaat GKE Kanaan sangat penting dalam membangun kesaksian hidup di tengah-tengah masyarakat.

Peran kaum ibu jemaat GKE Kanaan dapat juga ditumbuhkan dengan melihat keteladanan Yesus. Rohi menerangkan bahwa terdapat beberapa nilai yang menguatkan panggilan pelayanan misi kaum ibu melalui keteladan Yesus, yaitu: ${ }^{24}$ pertama, Yesus menjadi inisiator misi. Keteladanan Yesus ini dapat diambil oleh kaum ibu, dimana menjadi inisiator misi atau menjadi pelaku-pelaku misi. Keteladan Yesus yang menjadi inisiator misi inilah yang mendorong kaum ibu untuk menjadi pelaku-pelaku misi dalam segala situasi. Panggilan misi merupakan panggilan mulia yang dipikul oleh kaum ibu. Kedua, Menjadi penguat bahwa Yesus memperlengkapi. Yesus bertindak memberikan kuasa kepada para murid pada masa lampau dalam pemberitaan Injil. Hal serupa dalam dialami dan terjadi bagi kaum ibu. Dengan kata lain, ketika kaum ibu diberikan kesempatan dan anugrah dalam melakukan misi Allah, maka pelayanan tersebut bukan hanya memberitakan Injil keselamatan, namun juga harus menghidupi Injil tersebut oleh pertolongan kuasa Roh Kudus. ${ }^{25}$ Inilah yang menjadi dasar penguat dan motivasi bagi kaum ibu dalam melaksanakan pelayanan misi.

Upaya-upaya dalam meningkatkan peran kaum ibu dalam pelayanan misi di atas, diharapkan dapat memotivasi kaum ibu jemaat GKE Kanaan dalam Gereja."

${ }^{24}$ Rohi, "Hakekat Misi Yesus Kepada Para Murid Dalam Matius 10: 1-15 Sebagai Dasar Misi

25 Yohanes Hasiholan Tampubolon, "Kontekstualisasi Metodologi Misiologi Paulus Dalam Dunia Kontemporer," Excelsis Deo: Jurnal Teologi, Misiologi, Dan Pendidikan 3, no. 2 (2019): 13-25, https://doi.org/10.51730/ed.v3i2.13. 
mendukung dan terlibat dalam pelayanan misi. Implikasi peran kaum ibu dalam misi ini tentu tidak mudah. Dibutuhkan komitmen gereja dalam memperlengkapi kaum ibu serta komitmen kesetiaan dari kaum itu sendiri. Dengan adanya dukungan dari gereja serta komitmen kesetiaan kaum ibu, pelayanan misi di masa sulit sekalipun dapat dilakukan dengan baik. Dengan demikian, peran misiologi kaum ibu jemaat GKE Kanaan Palangka Raya tetap eksis dan berjalan dengan baik.

\section{KESIMPULAN}

Berdasarkan pembahasakan di atas, dapat diperoleh informasi peran misiologi kaum ibu jemaat GKE Kanaan Palangka Raya. Peran misiologi tersebut dapat ditemukan dari peran praktis kaum ibu dalam pelayanan misi. Peran tersebut yaitu kaum ibu menjadi penanggung jawab pengumpulan dana dalam rangka mendukung pelayanan misi di Pos PI binaan jemaat GKE Kanaan. Peran praktis lainnya yaitu kaum ibu jemaat Kanaan memberikan kesaksian kepada masyarakat dengan melakukan pelayanan sosial membagi-bagikan sembako pada masyarakat yang kekurangan. Dampak pandemi covid-19 membuat kondisi keuangan dan kebutuhan sehari-hari jemaat maupun masyarakat terganggu. Pelayanan misi lainnya dilakukan oleh kaum ibu jemaat GKE Kanaan dengan giat berbagi renungan firman Tuhan melalui media sosial facebook maupun WhatsApp. Melalui media sosial ini menjadi kesempatan bagi kaum ibu untuk berbagi kesaksian dan pengalamam hidup terutama dalam menghadapi permasalahan kehidupan karena dampak pandemi covid-19. Kemudian untuk mendorong dan meningkatkan peran kaum ibu jemaat GKE Kanaan dalam misi, didukung oleh 
faktor pembinaan dari gereja dan komitmen kesetiaan yang dimiliki oleh kaum ibu itu sendiri. Kesetiaan itu mencakup nilai bersaksi, bersekutu, dan melayani Tuhan.

\section{DAFTAR PUSTAKA}

Chang, William. Menggali Butir-Butir Keutamaan. Yogyakarta: Kanisius, 2002.

Gandaputra, Edwin. "Memikirkan Ulang Aplikasi Penginjilan Pribadi Pada Masa New Normal." Saint Paul's Review 1, no. 1 (2021): 29-45.

Jemali, Maksimilianus. "Upaya Pastoral Untuk Meningkatkan Peran Kaum." Jurnal Pendidikan Dan Kebudayaan 10, no. 2 (2018): 204-18. http://unikastpaulus.ac.id/jurnal/index.php/jpkm/article/view/171.

Kapojos, Shintia Maria, Randy Frank Rouw, and Hengki Wijaya. "Implikasi Kehidupan Perempuan Yahudi Bagi Gereja Masa Kini.” Evangelikal: Jurnal Teologi Injili Dan Pembinaan Warga Jemaat 3 (2019): 136-43.

Kristian, Alvin Budiman. "Pemberitaan Injil Di Tengah Masyarakat Pluralis." Excelsis Deo: Jurnal Teologi, Misiologi, Dan Pendidikan 3, no. 1 (2019): 123-32. https://doi.org/10.51730/ed.v3i1.5.

LPMI, Tim. Latihan Pemuridan Dasar. Surabaya: Lembaga Pelayanan Mahasiswa Indonesia, 2007.

Malik. "Implementasi Menjadi Jemaat Yang Misioner." Phronesis: Jurnal Teologi Dan Misi 2, no. 2 (2019).

Malik, Rikarni Zai, Sandi Ziliwu, and Lelis Sakerebau. "Pemberdayaan Kaum Ibu Dalam Pelayanan Di Gksi Sektor Kuala Behe Kecamatan Kuala Behe Kabupaten Landak Kalimantan Barat.” Jurnal PKM Setiadharma 1, no. 1 (August 18, 2020): 19-26. https://doi.org/10.47457/jps.v1i1.41.

Rohi, Yohanis Udju. "Hakekat Misi Yesus Kepada Para Murid Dalam Matius 10 : 1-15 Sebagai Dasar Misi Gereja." Missio Ecclesiae 3, no. 2 (2014): 16282. https://doi.org/https://doi.org/10.52157/me.v3i2.42.

Santosa, Nur Budi. "Pelayanan Sosial Sebagai Konteks Refleksi Aktivitas Misiologi." Antusias: Jurnal Teologi Dan Pelayanan 2, no. 4 (2013).

Siahaya, Nunuk Rinukti. "Peranan Perempuan Menurut Perjanjian Baru Bagi Perkembangan Kepemimpinan Perempuan Di Dalam Gereja." Jurnal Teruna Bhakti 1, no. 1 (2018): 33-41. http://ejournal.stakterunabhakti.ac.id/index.php/teruna/article/view/9. 
Simamora, Elim. "Peranan Perempuan Dalam Gereja : Eksposisi 1 Korintus 14 : 34." Kerugma: Jurnal Teologi Dan Pendidikan Kristen 1, no. 2 (2019): 75-89.

Simon, Simon, and Semuel Ruddy Angkouw. "Perintisan Gereja Sebagai Bagian Dari Implementasi Amanat Agung." Manna Rafflesia 7, no. 2 (April 30, 2021): 210-34. https://doi.org/10.38091/man_raf.v7i2.142.

Situmorang, Jonar. "Model Misi Perkotaan Rasul Paulus Di Korintus." Missio Ecclesiae 7, no. 2 (2018): 188-228.

Sondopen, Dorce. "Relasi Antara Penginjilan Dan Pemuridan Untuk Pertumbuhan Gereja." Excelsis Deo: Jurnal Teologi, Misiologi, Dan Pendidikan 4 (2019): 95-105.

Stevanus, Kalis. "Mengimplementasikan Pelayanan Yesus Dalam Konteks Misi Masa Kini Menurut Injil Sinoptik.” FIDEI: Jurnal Teologi Sistematika Dan Praktika 1, no. 2 (2018): $284-98$. https://doi.org/10.34081/fidei.v1i2.21.

Sugiyono. Metode Penelitian Pendidikan. Bandung: Alfa Beta, 2016.

Surya, Agus. "Peran Perempuan Dalam Ibadah: Dialektika Politik Dan Teologi Tubuh.” SOTIRIA (Jurnal Theologia Dan Pendidikan Agama Kristen) 3, no. 2 (2020): 84-94. https://doi.org/10.47166/sot.v3i2.22.

Tacoy, Selvester Melanton. "Pelayanan Dalam Konteks Masyarakat Perkotaan." Jurnal Teologi Kontekstual Indonesia 1, no. 1 (2020): 36. https://doi.org/10.46445/jtki.v1i1.300.

Tampubolon, Yohanes Hasiholan. "Kontekstualisasi Metodologi Misiologi Paulus Dalam Dunia Kontemporer." Excelsis Deo: Jurnal Teologi, Misiologi, Dan Pendidikan 3, no. 2 (2019): 13-25. https://doi.org/10.51730/ed.v3i2.13.

Waruwu, Adieli, and Samuel Purdaryanto. "Strategi Pelayanan Misi Dimasa Pandemi Coronavirus Desease 2019." Manna Rafflesia 7, no. 2 (2021): 419-40. https://doi.org/10.38091/man_raf.v7i2.171. 